BOGUMIE SZADY - LUBLIN

\title{
PRAWO PATRONATU \\ WIKARIUSZY KOLEGIACKICH W ZAMOŚCIU \\ W ŚWIETLE REFLEXIONES SUPER IURE PRAESENTANDI \\ Z 1770 ROKU
}

\section{Tło historyczne}

Wikariusze kolegiaccy w Zamościu nie byli dotąd przedmiotem odrębnego studium monograficznego. Nieco uwagi poświęcił im F. Stopniak w pracy poświęconej kapitule zamojskiej. Pominął jednak dość istotny, z punktu widzenia funkcjonowania tego kolegium, problem rekrutacji nowych wikariuszy oraz ich położenie formalno-prawne'.

Z kolegiatą zamojską związani byli wikariusze dwóch kategorii, które źródła określają mianem „decanales” i „canonicales”. Zgodnie z treścią dokumentu fundacyjnego kapituły kolegiackiej wystawionego 5 lipca 1600 roku przez Jana Zamoyskiego, hetmana i kanclerza wielkiego koronnego, dziekan miał utrzymywać 5 wikariuszy (dwóch $z$ uposażenia dziekana infułata oraz trzech $z$ beneficjum parafialnego w Szczebrzeszynie) - „vicarii decanales" ${ }^{\prime 3}$. Ten sam dokument określał uposażenie dla czterech innych wikariuszy. Mieli oni partycypować, wspólnie ze scholastykiem, ezterema kanonikami i kaznodzieją kolegiackim, w dochodach z dóbr Chmielek, Rakówka i Wola Chmielecka. Tę grupę wikariuszy źródła określają mianem „fundi Chmielek” lub

' F. S t o p n i a k, Dzieje kapituly zamojskiej, Lublin 1962, s. 144-158.

${ }^{2}$ Erekcja wikariatu 1600 (tytuł mylny, gdyż poszyt zawiera akta procesu o prawo patronatu wikariuszy kolegiackich z 1771 roku), WAPL. Zespół Kolegiata Zamojska, nr 61, s. 3.

${ }^{3}$ J. A. Wa dow s k i, Wiadomości o profesorach Akademii Zamojskiej, Warszawa 1899. 1900, 's. 84. Obowiązek utrzymywania przez dziekana kolegiackiego pięciu wikariuszy potwierdzają wizytacje kolegiaty z 1630 i 1638 roku, AAL. Rep60 A149, k. 174; AAL. Rep60 Al50, k. $135 \mathrm{v}$. 
„canonicales"4. Liczba wikariuszy kolegiackich, ustalona w dokumencie fundacyjnym, nie zmieniła się do II połowy XVIII wieku. Dekret reformacyjny wizytacji biskupa Turskiego z 29 stycznia 1770 roku podkreślił obowiązek utrzymywania pięciu wikariuszy przez dziekana oraz czterech przez scholastyka i kanoników „fundi Chmielek”.

Określona w dokumencie fundacyjnym liczba wikariuszy kolegiackich nie została prawdopodobnie nigdy osiagnięta ${ }^{6}$. Jedną z przyczyn takiego stanu rzeczy był prowizyjny charakter obsady wikarii, które nie posiadały charakteru odrębnego beneficjum kościelnego. Prałaci i kanonicy samodzielnie decydowali o powierzeniu obowiązków wikariusza duchownemu, wyznaczając mu za ich pełnienie określone honorarium roczne (,salarium") ${ }^{7}$. Zdarzało się jednak, tak jak w 1659 roku, że stanowiska wikariuszy były nieobsadzone, a honoraria zatrzymywat np. dziekan ${ }^{8}$.

W II połowie XVIII wieku zmieniło się położenie formalno-prawne wikariuszy kanonickich („,canonicales”). 20 maja 1765 roku w Skierbieszowie została zawarta umowa między scholastykiem i kanonikami "fundi Chmielek” a wikariuszami kolegiackimi, która wyznaczała wikariuszom stałą pensję $\mathrm{z}$ dóbr Chmielek w wysokości 500 złotych rocznie?. Następnego dnia biskup Walenty Wężyk zatwierdził to porozumienie, przyznając lub też uznając (,conservamus") prawo patronatu scholastyka i czterech kanoników nad wikariuszami kanonickimi' ${ }^{10}$. Kolejnego dnia, 22 maja, wikariusze kolegiaccy otrzymali prezentę ze strony scholastyka oraz kanoników kolegiackich, aby już 24 maja pojawić się przed biskupem, z prośbą o instytucję kanoniczną której biskup dokonał' ${ }^{1 !}$.

${ }^{4}$ Wa dowski, Wiadomosici, s. 83-84. Obowiązek utrzymywania przez prałatów i kanoników kolegiackich czterech wikariuszy potwierdzają wizytacje kolegiaty z 1630 i 1638 roku, AAL. Rep60 A149, k. 174; AAL. Rep60 Al 50, k. 138.

${ }^{5}$ AAL. Rep60 A134, s. 508-509.

${ }^{6} \mathrm{~S}$ top $\mathrm{n}$ i a k, Dzicje, s. 145, 149; AAL. Rcp60 A 150, k. 138.

${ }^{7}$ Akta sądowe zawierają wiele wpisów potwierdzających prowizje, np. 17 grudnia 1616 roku Mikołaj Kiślicki, dziekan kolegiacki, udzielił prowizji na wikarię zamojską Samuelowi Piwko, wyznaczając mu roczną pensję w wysokości 70 złotych (AAL. Rep60 Al07, k. 83v). Podobną prowizję otrzymał 18 kwietnia 1642 r. Piotr Niekraszewicz od Jakuba Skwarskiego, dzickana kolegiackiego, z tym że honorarium wyniosło 100 zł (AAL. Rep60 All3, k. 5). Podobne pensje otrzymywali wikariusze kanoniccy, np. 8 marca 1631 roku Wawrzyniec Dąmbrowski - 70 złotych (AAL. Rep60 Al10, k. 151v), 27 marca 1638 roku Jakub Siedmiogrocki - 100 złotych (AAL. Rep60 A111, k. 412).

${ }^{8} \mathrm{~S}$ to p n i a k, Dzieje, s. 145

${ }^{9}$ AAL. Rep60 A133, k. 277-278.

10 „Jam autem ius patronatus eorundem vicariorum fundi Chmielek penes perillustrem reverendum scholasticum et quatuor canonicos eiusden fundi uti illis competens conservamus nunc etiam perpetuum imo verius toties quoties sive post cessum aut decessum occurerit eiusdem vicariatus vacatio", AAL, Rep60 A133, k. 279.

${ }^{11}$ „(...) comparuerunt personaliter admodum reverendi Michael Bogucki, Antonius Piecek, $\Lambda$ ndreas Kisielowski adhucusque per provisionem sibi a patres reverendos scholastico et 
Niepozorna na pierwszy rzut oka wzmianka w dokumencie biskupa Wężyka z 21 maja 1765 roku, zmieniająca sposób obsady wikariuszy ,fundi Chmielek", oznaczała w rzeczywistości przekształcenie wikarii prowizyjnych w samodzielne beneficja kościelne (wikarie wieczyste). Wizytacja biskupa Turskiego z 29 stycznia 1770 roku inicjatywę takiej zmiany przypisuje samym wikariuszom kanonickim, którzy chcieli w ten sposób upodobnić się do kapituły i odróżnić zdecydowanie od wikariuszy dziekańskich. Pragnęli oni, podobnie jak scholastyk i kanonicy „fundi Chmielek”, obejmować swoje stanowiska $z$ prezenty ordynatów zamojskich ${ }^{12}$. Można z dużym prawdopodobieństwem przypuszczać, że wynikało to $z$ chęci uniezależenienia materialnego od kapituły, która zaniedbywała wypłatę świadezeń dla wikariuszy prowizyjnych. Realizacja postulatu kapituły oznaczałaby podział dóbr Chmielek między kapitułę i wikariuszy. Wikariusze zgodzili się jednak odstąpić od swoich żądań i zawarli porozumienie ze scholastykiem i kanonikami, o którym była mowa w poprzednim paragrafie. Zrezygnowali w nim z wszelkich pretensji do dóbr Chmielek ${ }^{13}$.

Przyznanie prawa patronatu wikariuszy „fundi Chmielek” scholastykowi i kanonikom kolegiackim spotkało się ze sprzeciwem ordynatów zamojskich jako potomków fundatora kapituły i wikariuszy. Klemens Zamoyski, VIII ordynat (1760-1767), złożył protestację na ręce notariusza apostolskicgo $w$ tej sprawie. W opinii członków kapituły była ona bezzasadna, zaś sam ordynat, gdy został dobrze poinformowany o charakterze sporu przez nowego biskupa chełmskiego Feliksa Turskiego, zdecydował się nie nadawać sprawie dalszego biegu' ${ }^{14}$.

Po objęciu przez Antoniego Piecka, wikariusza kolegiackiego, prepozytury szpitalnej w Zamościu, wybuchł spór o opróżnione przez niego beneficjum. 20 grudnia 1770 roku prezentę na nie $\mathrm{z}$ rąk scholastyka i czterech kanoników „fundi Chmielek" otrzymał Wojciech Adamski, student seminarium zamojskiego ${ }^{15}$. W cztery dni później (24 grudnia 1770 roku) Jan Jakub Zamoyski,

canonicis fundi Chmielek inscriptam iurati reverendus quoque Martinus Baranski per simplicem applicationem eidem ecclesiae serviens vicarii, nunc vero vigore concordati (...) ab eodem scholastico et canonicis praesentati sub die 22 maii anno nunc currentis $1765^{\prime \prime}$, AAL. Rep60 A133, k. 252-252v.

${ }^{12}$,Quia vero moderni vicarii quatuor in aequa lance cum decanalibus vicariis in erectione, quo ad ius vocationis suae ad vicariatum et conservationis positi, non contenti, quod per provisionem officiosam canonicorum suorum sive praesentationem ad ordines et ecclesiam vocentur et promoveantur, non minus ac vicarii decanales vocari et promoveri ab origine solebant et solent, sed ob aequalem in bonis Chmielek fundationem aequaliter cum suis canonicis per praesentationem promoveri ab illustrissimo colegiatae patrono iterato cupiunt", AAL. Rep60 A134, s. 509.

13 "Possessionemque regiminis praefatorum bonorum minime perturbarc nec aliquibus litium gradibus impetere se obstrinxerunt", AAL. Rep60 A133, k. 277v.

${ }^{14}$ Zob. aneks, s. 240.

is WAPL. Zespół Kolegiata Zanojska, nr 449. 
IX ordynat (1767-1778) zaprezentował na wakujące beneficjum swojego kandydata - Jana Wojciechowskiego ${ }^{16}$. Na początku roku następnego (1 lutego 1771 roku) ordynat złożył manifestację w sądzie metropolitalnym we Lwowie, w której oskarżył scholastyka i kanoników o przywłaszczenie praw patronackich i niedopuszczanie do instytucji Woyjciechowskiego na wakujące beneficjum ${ }^{17}$. Trudno podać przyczyny skierowania sprawy od razu do sądu II instancji, z pominięciem sądu diecezjalnego. Zwłaszcza, że scholastyk i kanonicy zamojscy formalną protestację, skierowaną przeciw prezencie dokonanej przez ordynata zamojskiego, złożyli w konsystorzu chełmskim dopiero 22 lutego 1771 roku. Wyrazili przy tej okazji wolc powrotu do starego sposobu powoływania wikariuszy kolegiackich przez prowizję. Zawarty w dokumencie biskupa Wężyka z 1765 roku ustęp o przyznaniu im prawa patronatu określili jako spełnienie woli samych wikariuszy („nonnisi affectationi vicariorum annuendo"). Zaproponowali jednocześnie udzielenie takiej prowizji, zgodnie ze starym zwyczajem, Wojciechowi Adamskiemu, którego wcześniej prezentowali na to beneficjum ${ }^{18}$.

25 lutego, trzy dni po wspomnianym proteście, Jan Wojciechowski zgłosił się w konsystorzu chełmskim z prośbą o instytucję na wikarię kolegiacką na podstawie prezenty otrzymanej od Jana Jakub Zamoyskiego. Spotkało się to z ponownym sprzeciwem scholastyka i kanoników, którzy byli reprezentowani przez Dominika Rydulskiego. Wyrokiem przedstanowczym sądu (,sententia interlocutoria") instytucja został wstrzymana, aż do wyjaśnienia sprawy sposobu obsady wikarii kolegiackich. Decyzja ta spotkała się ze sprzeciwcm ordynata, który 29 kwietnia 1771 złożył apelację w sądzie metropolitalnym 1wowskim ${ }^{19}$. Wobec braku wyroku ostatecznego (,sententia definitiva") odnośnie spornego prawa patronatu w sądzie I instancji, 13 maja 1771 sąd metropolitalny wydał wyrok odsyłający („decretum remissionis”) sprawę do ponownego rozpatrzenia w sądzie $I$ instancji ${ }^{20}$.

26 czerwca 1771 roku przed biskupem chełmskim Antonim Onufrym Okęckim stawili się pełnomocnik ordynata Jana Jakuba Zamoyskiego - Tadeusz Zakrzcwski, starosta szczebrzeski oraz Dominik Rydulski, który reprezentował scholastyka i pozostałych kanoników kolegiackich. Posiedzenie miało zdecydować o przyznaniu praw patronackich względem wikariuszy kolegiackich ordynatom zamojskim lub przywróceniu starego sposobu obsady przez prowizje ze strony scholastyka i czterech kanoników „fundi Chmielek”. Powodem w tej sprawie, zgodnie z protestacjami z 22 i 25 lutego, był scholastyk oraz kanonicy zamojscy fundi Chmielek ${ }^{21} .21$ sierpnia 1771 roku sąd biskupi

${ }^{16}$ AAL. Rep60 A137, k. 88v.

${ }^{17}$ AALw. K.K. 44, s. 168-170.

${ }_{18}^{18}$ AAL. Rep60 A134, s. 419-420.

19 AALw. K.K. 44, s. 251-252.

${ }^{20}$ AALw. K.K. 44, s. 257-261; AAL. Rep60 A136, s. 42.

${ }^{21}$ Zapis w księdze otwierający sprawe pod datą 26 czerwca („Pro illustro et magnifico Joanne Zamoyski ordinato Zamoscense palatino Podoliae actore et citato contra illustres 
w Skierbieszowie uznał rację scholastyka oraz kanoników kolegiackich i wydał wyrok ostateczny, w którym przywrócił prowizyjny sposób obsady wikariuszy $^{22}$. Ordynat zamojski złożył odwołanie od wyroku do sądu metropolitalnego we Lwowie, który 10 grudnia 1771 roku uznał jego argumentację i przyznał prawo patronatu nad wikariuszami kanonickimi ordynatom zamojskim ${ }^{23}$. Kilka dni później (23 grudnia 1771 roku) scholastyk oraz kanonicy kolegiaccy złożyli w sądzie metropolitalnym zapowiedź odwołania od tej decyzji do Stolicy Apostolskiej ${ }^{24}$.

24 stycznia 1772 roku przed oficjałem krasnostawskim pojawił się ponownie z prośbą o instytucję na wikarię zamojską Jan Wojciechowski, powołując się na wyrok sądu lwowskiego z 10 grudnia 1771 roku. Zapowiedział jednocześnie ugodę między ordynatem i kanonikami, w myśl której kanonicy i scholastyk mieli odstąpić od zapowiedzianej apelacji ,sub certis contidionibus"2s. 6 marca 1772 roku scholastyk i kanonicy odstapili od apelacji do Rzymu i Jan Wojciechowski został instytuowany na wikarię zamojską na podstawie prezenty ordynata ${ }^{26}$. Od tego momentu wikariusze kolegiaccy „fundi Chmielek" byli prezentowani przez ordynata ${ }^{27}$, w odróżneniu od wikariuszy dziekańskich powoływanych przez prowizję ${ }^{28}$.

admodum revercndum scholasticum et quatuor canonicos fundi Chmielek insignis ecclesiae collcgiatae Zamoscensis citatos et actores" [podkr. autora]) może sugerować pozew wzajemny, lecz cały bieg sprawy, a zwłaszcza treść wyroku ostatecznego z 21 sierpnia pozwalają twierdzić, że powodem byli tutaj scholastyk i kanonicy (,Inter illustres admodum reverendum scholasticum et quatuor canonicos insignis ecclesiae collegiatae Zamoscensis fundi Chmielek actores et illustrissimum magnificum Jacobum Zamoyski (...) citatum" [podkr. autora]), AAL. Rep60 A136, s. 4, 41.

${ }^{22}$ AAL. Rep60 A 136, s. 41-52.

${ }^{23}$ AAL. Rep60 A 137, k. 89; WAPL. Zespół Kolegiata Zamojska, nr 61 (AMBK 1926).

${ }^{24}$ AAL. Rep60 A137, k. 89v.

${ }^{25}$ AAL. Rep60 A137, k. 88v-89v (,,iuris passivi subiectorum ad vicariatus promovendorum, iudicii capitularis, regiminis bonorum fundationalium, difformitatis vicariorum fundi decanalis").

${ }^{26}$ AAL. Rep60 A137, k. $103 \mathrm{v}-104 \mathrm{v}$.

${ }^{27}$ Michał Bogucki i Marcin Barański instytuowani 3 kwietnia 1772 na podstawie prezenty ordynata z 18 marca (AAL. Rep60 A137, k. 132-132v); Antoni Piecck, prepozyt szpitalny zamojski instytuowany 3 kwietnia 1772 roku (po śmierci Andrzeja Kisielowskiego) na podstawie prezenty ordynata $z 18$ marca (AAL. Rep60 A137, k. 133v); Kajetan Derbedroszewicz instytuowany 13 listopada 1772 (po przejściu Michała Boguckiego na prebendę różańcową) na podstawie prezenty ordynata z 12 października (AAL. Rep60 A137, k. 220); Mikołaj Maciejowski instytuowany $21 \mathrm{kwietnia} 1773$ roku (po przejściu Antoniego Piecka do kościoła parafialnego w Botorzu), na podstawie prezenty ordynata (AAL. Rep60 A137, k. 293); Wojciech Simulski instytuowany 14 kwietnia 1774 roku (po przejściu Jana Wojciechowskiego na prebendę różańcową w kościele tomaszowskim) na podstawie prezenty ordynata z 9 marca (AAL. Rep60 A137, k. 371).

${ }^{28}$ Prowizję taką otrzymali: 6 listopada 1772 roku Mikołaj Maciejowski, student seminarium zamojskiego (AAL. Rep60 A137, k. 219v) oraz 28 lutego 1774 roku Michał Witawski, Józef Prustan i Franciszek Rzeszowski od Aleksandra Trembińskiego, kanonika katedralnego 


\section{Data powstania i autorstwo}

Przed próbą określenia czasu powstania oraz autora rękopisu zatytułowanego „Reflexiones super iure praesentandi vicarios ad ecclesiam collegiatam Zamoscensem scholastico et canonicis primaevae fundationis fundi Chmielek competente"29 należy postawić pytanie o jego charakter formalno-prawny. Treść, struktura oraz sposób formułowania wypowiedzi wskazują, że stanowił on element postępowania dowodowego w kanonicznym procesie sądowym. Zawiera on uzasadnienie i argumenty powoda (tj. scholastyka i kanoników) do tzw. artykułów dowodowych w sprawie o obsade wikarii kolegiackich w Zamościu ${ }^{30}$.

Poszerzony i nieco zmieniony tekst tego rękopisu, znajduje się w odpisie w aktach sądowych biskupa Okęckiego pod datą 26 czerwca 1771 roku $^{31}$. Jego tytuł w odpisie jest nieco inny: „Rationes ex parte illustrium canonicorum Zamoscensium fundi Chmielek pro iure vocandi vicarios ad ecclesiam collegiatam Zamoscensem scholastico et quattuor canonicis eiusdem collegiatae competente anno Domini 1771 die 26 mensis iunii" ${ }^{32}$. Dość trudno określić precyzyjnie relację między rękopisem w poszycie i odpisem zawartym w aktach sądowych biskupa Okęckiego. Poszyt powstał z pewnością wcześniej, na co wskazuje korekta błędów oraz uzupełnienia dokonane w wersji wpisanej do akt sądowych. Poprawki zostały wprowadzone prawdopodobnie na skutek odpowiedzi ze strony Zamoyskich na argumenty kanoników. Wskazuje na to wyraźnie tytuł pisma przedstawionego przez pełnomocnika ordynata („Replicatio ad reflectiones super iure patronatus et praesentandi vicarios ad ecclesiam insignis collegiatae Zamoscensis acsi scholastico et canonicis fundi Chmielek competente pro termino ex literis cridae coincidenti die 25 . februarii 1771 anno facta") oraz wymiana poglądów odnośnie czasu powstania kolegiaty. W poszycie, w punkcie 3, pojawia się fragment: „A condita collegiata per annos 130", który został poprawiony i w aktach sądowych jest już: „A condita collegiata per annos 170 ". Poprawka jest reakcja na zdanie zamieszczone w odpowiedzi Ordynacji: „Condita ecclesia collegiata non est ab anno 130 sed ab anno $170^{\prime \prime 3}$.

lwowskiego, prepozyta katedralnego chełmskiego, dziekana zamojskiego (AAL. Rep60 A137, k. $353 \mathrm{v}-354)$.

${ }^{29}$ WAPL, Zespół Akt Kolegiaty Zamojskiej, nr 64.

${ }^{30}$ Wskazuje na to sformułowanie użyte w aktach sądowych: ,ad lectionem probationum, exceptionum et replicationum in seorsivis schedis descriptarum", AAL. Rep60 A136, s. 6 Artykuły dowodowe (,articuli probandi”) były to pozycje sporne, które były przedmiotem dowodzenia każdej ze stron procesowych, E. R i $t$ n e r, Prawo kościelne katolickie, t. 2, Lwów 1907, s. 70.

31 Zob. s. 224, przyp. 21.

${ }^{32}$ AAL. Rep60 A 136, s. 6-7.

${ }^{33}$ AAL. Rep60 A136, s. 24. 
Można z dużym prawdopodobieństwem przyjać, że rękopis w poszycie („Reflexiones”) był pierwszą wersją argumentacji kanoników, która została przedstawiona ordynatom. W reakcji na nie, przygotowano odpowiedź (,,Replicatio ad reflexiones"), przedstawioną z kolei scholastykowi i kanonikom. Uwzględnienie uwag Ordynacji pozwoliło scholastykowi i kanonikom zredagować poprawioną wersję swojego uzasadnienia („Rationes”). Akta sądowe zawierają odpowiedź ze strony Ordynacji („Replicatio ad reflexiones”) oraz poprawioną argumentację scholastyka i kanoników („Rationes”) ${ }^{34}$.

Dość skomplikowane wzajemne relacje treściowe trzech wymienionych wyżej tekstów ukazuje zamieszczone niżej zestawienie. Można oczywiście przyjąc istnienie innych dokumentów nie odnalezionych w czasie kwerendy ${ }^{35}$, jednak kolejność podana poniżej nie pozostawia wattpliwości:

„Reflexiones super iure praesentandi vicarios ad ecclesiam collegiatam Zamoscensem scholastico et canonicis primaevae fundationis fundi Chmielek competente" (poszyt W WAPL, 1770-1771 rok)

Część I

punkt 1

punkt 2

punkt 3

punkt 4

punkt 5

punkt 6

punkt 7

punkt 8

punkt 9

punkt 10

punkt 11

Część II

punkt 1

punkt 2

punkt 3

punkt 4

punkt 5
„Replicatio ad reflectiones super iure patronatus et praesentandi vicarios ad ecclesiam insignis collegiatae Zamoscensis acsi scholastico et canonicis fundi Chmielek competente pro Termino ex literis cridae coincidenti die 25 . februarii 1771 anno facta" (tekst w aktach sądowych)

Ad. 1

Ad. 2

Ad, 3

[brak odpowiedzi na punkt 4]

Ad. 4 [odpowiedź na punkt 5]

Ad. 5 [odpowiedź na punkt 6]

Ad. 6 [odpowiedź na punkt 7]

Ad. 7 [odpowiedź na punkt 8]

Ad. 8 [odpowiedź na punkt 9]

Ad. 9 [odpowiedź na punkt 10]

Ad. 10 [odpowiedź na punkt 11]

„Rationes ex parte illustrium canonicorum Zamoscensium fundi Chmielek pro iure vocandi vicarios ad ecclesiam collegiatam Zamoscensem scholastico et quattuor canonicis eiusdem collegiatae competente anno Domini 1771 die 26 mensis iunii" (tekst w aktach sądowych)

\section{Część I}

punkt 1 poszerzony

punkt 2

punkt 3

punkt 4 poszerzony

punkt 5 poszerzony

[brak całego punktu 6]

punkt 7 poszerzony

punkt 8

punkt 9

punkt 10

punkt 11

Część II

punkt 1 poszerzony

punkt 2

punkt 3

punkt 4

punkt 5

punkt 6

${ }^{34}$ AAL. Rep60 A136, s. 6-29.

3 Poza obszarem zainteresowania pozostał najpóźniejszy $z$ odnalezionych rękopisów, zawicrający argumenty scholastyka i kanoników, a przedstawiony prawdopodobnic $\mathrm{w}$ sądzie metropolitalnym w odpowiedzi na apelację ordynata od wyroku z 21 sierpnia 1771 roku, WAPL, Zespól Akt Kolegiaty Zamojskiej, nr 61. 
Wobec braku bezpośrednich informacji, nie można jednoznacznie i pewnie określić autora oraz dokładnego czasu powstania „Reflexiones”. Podane wyżej informacje oraz treść rękopisu wskazują na lata 1770-1771 jako czas jego powstania. W tekście (punkt 3) znajduje się fragment: ,ut constat ex decreto visitationis collegiatae per illustrissimum et reverendissimum Turski episcopum Hełmensem anno praesenti expedite”. W punkcie 9 zaś można znaleźć fragment: "Idem testatur novissimum decretum visitationis collegiatac Zamoscensis per illustrissimum episcopum Turski anno practcrito latum et propositum“. Wizytacja biskupa Turskiego, o czym była mowa wyżej, miała miejsce w styczniu 1770 roku. Cytowany fragment $\mathrm{z}$ punktu 3 został zmieniony w odpisie z 1771 roku zawartym w aktach sądowych. W miejsce zwrotu: ,anno praesenti", pojawił się: ,anno immediate praeterito" ${ }^{\text {"36 }}$.

Bardziej skomplikowane jest ustalenie autorstwa rękopisu. Wiele wskazuje na Dominika Rydulskiego, kanonika „,fundi Chmielek”, który był pełnomocnikiem scholastyka i pozostałych kanoników w czasie posiedzenia sądu 26 czerwca 1771 roku $^{37}$. Przemiawia za tym prawnicze przygotowanie Rydulskiego, który w latach 1754-1784 był profesorem prawa kanonicznego w Akademii Zamojskiej i jej ostatnim rektorem ${ }^{38}$. Wspomniany w treści przykład obsady prebend kościoła kolegiackiego w Ołyce, wskazuje na dobrą znajomość sytuacji przy tym kościele. Dominik Rydulski, po zdobyciu tytułu bakałarza na Uniwersytecie Krakowskim został w 1743 roku, na wezwanie Akademii Zamojskiej, nauczycielem gramatyki w jej kolonii, która znajdowała się w Ołyce. Wizytował tę kolonic jeszcze w 1753 roku $^{39}$. Nie można wykluc'zyé, że pomocą służyli Rydulskicmu Baltazar Dulewski, kanonik katedralny i scholastyk kolegiacki ${ }^{40}$, Klemens Podziomkiewicz, Tomasz Karwosiecki oraz Andrzej Wątrobski, kanonicy ,fundi Chmielek” oraz profesorowie Akademii Zamojskiej ${ }^{4 !}$.

\section{Treść}

Punktem odniesienia dla analizy omawianego dokumentu musi być cel jego przygotowania. Można go określić na podstawie bezpośrednich wzmianek w treści, a także przez kontekst oraz tło historyczne jego powstania. Na pierwsze miejsce wysuwa się tutaj wykazanie bezprawności prawa patronatu ordynatów nad wikariuszami kolegiackimi (twierdzenie negatywne). Drugim ce-

${ }^{36}$ AAL. Rep60 A136, s. 11.

${ }^{37}$ Zob. s. 224.

${ }^{38} \mathrm{~W}$ a d ow s ki, Wiadomości, s. 57-58.

${ }^{39}$ L. Grze bi eń, Rydulski Dominik Jan, w: Polski Slownik Biograficzny (dalej: PSB), t. 33 , s. 427.

${ }^{40}$ B. Hor d y n s k i, Dulewski Baltazar, w: PSB, t. 5, s. 454.

${ }^{4}$ M. Chach a j, Wyksztatcenie profesorów Akademii Zamojskiej, w: Whregu akademickiego Zamościa, red. H. Gmiterek, Lublin 1996, s. 129, 135, 136, 140. 
lem było uzasadnienie prawa powoływania wikariuszy przez członków kapituły kolegiackiej (twierdzenic pozytywne). Można z dużym prawdopodobieństwem stwierdzić, że nie chodziło o potwierdzenie prawa patronatu kapituły nad wikariuszami kolegiackimi, lecz jedynic o udowodnienie prowizyjncgo sposobu ich powoływania. Wskazuje na to fakt, że dokument biskupa Wężyka z 1765 roku, który zmieniał sposób obsady wikariuszy kolegiackich z prowizyjnego na instytucyjny, został wydany $z$ woli samych wikariuszy i nie jcst wykluczone, że wbrcw scholastykowi i kanonikom zamojskim. Ponadto już w lutym 1771 roku, scholastyk i kanonicy - w cclu uniknięcia konfrontacji z ordynatem - wyrazili wolę powrotu do starcgo sposobu powoływania wikariuszy kolegiackich ${ }^{42}$.

Twierdzenie kanoników o bezprawności patronatu ordynatów i słuszności swoich kompetencji względem obsady wikarii kolegiackich zasadzało się na dwóch podstawowych faktach:

A. fundator kolegiaty, Jan Zamoyski, nie objął prawem patronatu wikarii kolegiackich $i$ ich obsadę pozostawił kanonikom;

B. przez 170 lat wikariusze byli powoływani przcz prowizję ze strony kanoników, a nie prezentę ze strony ordynatów.

Przed podjęciem analizy środków i metod dowodzenia przytoczonych wyżej faktów, należy odnieść się do punktu 4 rękopisu. Podniesiona tam kwestia prawa powoływania wikariuszy przez scholastyka i kanoników w oparciu o statuty kapituły kolegiackiej z 1609 roku została całkowicie pominięta w odpowiedzi ze strony Ordynacji. Można przypuszczać, że zagadnienie to zostało wyłączone przez sąd $z$ artykułów dowodowych. Sprawę komplikuje ponowne pojawienie się tego punktu, i to w rozszerzonej wersji, w argumentacji kanoników zamieszczonej w aktach sądowych ${ }^{43}$.

Całość dowodu została przez kanoników podzielona na dwie części. Pierwsza, składająca się z 11 punktów, zawiera fakty oraz argumenty, które popierają podane wyżej twierdzenia. W drugiej, zawierającej 5 punktów, znalazło się odniesicnie do tych faktów, które mogą całość dowodu podważyć, a zostały wskazane zapewne przez stronę ordynacką.

Dowodzenie twierdzcnia A. mogło oprzeć się tylko na domniemaniu faktu, gdyż brak jest dowodów bezpośrcdnich. W tym przypadku musiałoby to być wyraźne oświadczenie woli Jana Zamoyskiego, a takiego źródła nie podaja. W tej sytuacji kanonicy oparli swój dowód na pominięciu przez Jana Zamoyskiego problemu patronatu wikariuszy w dokumencie fundacyjnym kolegiaty, co, w ich interpretacji, świadczyło o woli fundatora by nie byli nim objęci ${ }^{44}$. Ten sposób dowodzcnia został poważnie osłabiony przez odpowiedź ze strony Ordynacji. Jej autor podkreślił m.in., że powstanie prawa patronatu nie wymaga wyrażcnia „expressis verbis” w dokumencie fundacyjnym lub

\footnotetext{
${ }^{42}$ Zob. s. 224.

4. AAL. Rep60 A136, s. 12.

${ }^{44}$ Zob. aneks, s. 233
} 
erekcyjnym beneficjum. Poparł to twierdzenie przepisami i literatura kanoniczną ${ }^{45}$. Zdecydowanie natomiast watpliwe jest oparcie praw kanoników na zdaniu: „quos vicarios ipse decanus deliget”. Ní można bowiem znaleźć takiego sformułowania $\mathrm{w}$ dokumencie fundacyjnym, co natychmiast podniosła strona ordynacka w swojej odpowiedzi ${ }^{47}$.

Uzasadnienie twierdzenia A. wymagało odniesienia się także do innego dokumentu związanego z powstaniem kolegium wikariuszy. Chodzi o nadanie im dóbr Chmielek, potwierdzone zapisem w aktach Trybunału Koronnego w Lublinie w 1601 roku. Znajduje się w nim fragment, w którym Jan Zamoyski wyraźnie zarezerwował dla siebie i swoich następców prawo patronatu wikarii kolegiackich. Kanonicy wskazywali na świecki charakter tego dokumentu, jako czynnik osłabiający jego wartość dowodową w sprawie o prawo patronatu jako ,ius spirituale annexum". Ponadto na podstawie braku egzekucji tego prawa przez samego fundatora i jego następców wnioskowali, że wspomniany fragment pojawił się $w$ dokumencie $z$ inicjatywy pisarza („privata voluntate scriptoris") i wbrew woli Jana Zamoyskiego ${ }^{48}$.

Dowodem pośrednim na poparcie twierdzenia A. miała być też powszechna praktyka powoływania wikariuszy przez kanoników obowiązująca w kościołach katedralnych i kolegiackich w Rzeczypospolitej. Powołali się tutaj na przykład kolegiaty w Ołyce fundacji Radziwiłłów. Kanonicy przypuszczali, że Jan Zamoyski kierując się przykładem innych kościołów kolegiackich w Rzeczypospolitej ich obsadę pozostawił kolegium kanonickiemu ${ }^{4}$. Strona ordynacka łatwo podważyła tę argumentację podając przykłady kościoła katedralnego w Krasnymstawie (patronat kolegium wikariuszy) oraz kolegiaty lubelskiej (patronat miejski) ${ }^{50}$.

Ostatnim elementem dowodowym twierdzenia A. jest argument zawarty w twierdzeniu B. W tej sytuacji twierdzenie B. staje się dowodem pośrednim twierdzenia A. Całość opiera się na logicznym założeniu: nie mogło było wolą fundatora objęcie wikariuszy kolegiackich patronatem ordynatów, skoro przez 170 lat nie dokonali oni żadnej prezenty ani w żaden sposób nie dochodzili tego przywileju.

Środkiem dowodowym, na którym kanonicy oparli twierdzenie B. były zarówno akta biskupie i konsystorskie, jak również protokoły wizytacyjne z XVII i XVIII wieku. Nie zachowały się w nich żadne ślady wpływu ordynatów na obsadę wikarii kolegiackich, podczas gdy wpisy prowizji kanonickich pojawiają się regularnie ${ }^{51}$. Kwerenda akt sądowych z XVII wieku potwierdza

\footnotetext{
${ }^{45}$ AAL. Rep60 A136, s. 22.

${ }^{46}$ Zob. aneks, s. 235.

${ }^{47}$ AAL. Rep60 A136, s. 24.

${ }^{48}$ Zob. aneks, s. 238-239.

${ }^{49}$ Zob. aneks, s. 236.

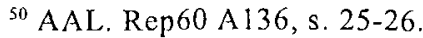

s) Zob. ancks, s. 235.
} 
zawartą w rękopisie opinię. O ile regularnie występują wpisy dokumentów prezentacyjnych ordynatów na kanonie i prałatury lub też beneficja parafialne, o tyle brak takich śladów w odniesieniu do wikarii kolegiackich.

Kanonicy podali ponadto przykłady zachowań ordynatów w XVII i XVIII wieku, które świadczyły o uznaniu i akceptacji istniejącej sytuacji, tj. obsady wikarii przez prowizję kanonicką. Chodziło tu m.in o dokument fundacyjny seminarium z 20 marca 1640 roku, w którym Katarzyna Zamoyska uznała prawo kanoników do powoływania wikariuszy kolegiackich. Zostało to potwierdzone przez Jana Zamoyskiego (III ordynata) w 1665 roku w sądzie grodzkim w Krasnymstawie ${ }^{52}$. Jako dowód kanonicy przytoczyli także decyzje biskupa Wężyka z 21 lipca 1765 roku o zmianie sposobu powoływania wikariuszy kolegiackich. Prowizja ze strony scholastyka i kanoników została zastąpiona udzielonym im prawem patronatu ${ }^{53}$.

Kwestionując uprawnienia ordynatów i podkreślając swoje, kanonicy wielokrotnie i bardzo mocno korzystali z przepisów o przedawnieniu („ex praescriptione"). Autor rękopisu odwoływał się tutaj zarówno do przepisów zawartych w prawie świcckim (Corpus iuris civilis) jak i w prawie kanonicznym (Corpus iuris canonici, dekrety soboru trydenckiego) ${ }^{54}$. Wykorzystał także decyzje Roty Rzymskiej oraz opracowania kanonistów nowożytnych takich jak: Hieronymus Gonzalez, Michael Angelus Paleoli, Stephan Wiestner, Fridericus de Senis (Federico Petrucci), Rolandus a Valle, Augustinus Barbosa, Corradus Pyrrhus ${ }^{55}$.

Prezentowany niżej dokument, chociaż dotyczy sporu o obsade wikarii kolegiackich, poruszył także zagadnienic sytuacji formalno-prawnej wikarii zamojskich w XVIII wieku. W latach 1765-177l zaszła tutaj istotna zmiana: nastapiło przekształcenie wikarii prowizyjnych w beneficja podlegające prawu patronatu. Bardzo wymowny jest wpis w aktach sądowych z 24 maja 1765 roku, gdzie pojawiły się aż trzy kategorie wikariuszy kolegiackich: „applicati", „provisi" i ,praesentati"s6. Świadomość istnienia dwóch typów wikariuszy kolegiackich: ,provisi” i ,praesentati” posiadał też autor analizowanego rękopisu. Wprowadził on ciekawe i, z punktu widzenia prawa kanonicznego, słuszne rozróżnienie między beneficjami oraz urzędami kościelnymi obsadzanymi na mocy prowizji, które nie podlegały prawu patronatu ${ }^{57}$. Przekształcenie prowizyjnych wikarii kolegiackich w beneficja kościelne odbyło sie w większości kapituł kolegiackich w Rzeczypospolitej znacznie wcześniej niż w Zamościu, np. w kolegiacie łowickiej w 1467 roku $^{58}$, zaś w kolegiacie tar-

\footnotetext{
${ }_{92}$ Zob. aneks, s. 235-236.

${ }^{53}$ Zob. aneks, s. 237.

Sob. przyp. 73, 74, 93, 94, 95, 105.

ss Zob. przyp. 75, 76, 77, 81, 87, 88, 89, 90, 96, 98, 99, 103.

${ }^{56}$ Zob. przyp. 11.

${ }^{57}$ Zob. aneks, s. 234.

${ }^{58}$ Jana Laskiego liber beneficiorum, wyd. J. Lukowski, t. 2, Gniczno 1881, s. 250.
} 
nowskiej w 1458 roku $^{59}$. W większości kościołów kolegiackich, inaczej niż w Zamościu, prawo patronatu wobec wikariuszy posiadali członkowie kapituły, natomiast instytucja należała do najwyższego ranga prałata ${ }^{60}$.

${ }^{59}$ ADT, KKol I.3, s. 47.

${ }^{60}$ Wskazują na to przykłady kolegiat w Kaliszu (ADWł. GAV21, s. 34), Kurzelowie (ADWł. GAV61, s. 54-55), Lowiczu (Jana Laskiego liber beneficiorum, s. 250), Opatowie (W. Gałąza, Kapitula kolegiacka w Opatowie w latach 1562-1983, Sandomierz 1997, s. 211-212), Skalbmierzu (AKMK, AV57, k. 100), Stanisławowie (J. K r e-t o s z, Organizacja archidiecezji lwowskiej obrzqdku lacinskiego od XV w. do 1772 roku, Lublin 1986, s. 152-153), Tarnowie (wyjątkiem był wioekantor, prezentowany przez dziedziców Tarnowa, ADT. KKol I.3, s. 47), Wieluniu (oprócz wikariuszy prezentowanych przez każdego członka kapituły - 3 prałatów i 4 kanoników - powinien być ósmy wikariusz z prezenty rajców wicluńskich, ADW1. GAV66, s. 27), Wiślicy (AKapK. AV53, k. 229v, 278) i Żółkwi (K r ę tos z, Organizacja, s. 152-153). 


\section{ANEKS $^{61}$}

[s. 1] Reflexiones super iure praesentandi vicarios ad ecclesiam collegiatam Zamoscensem scholastico el canonicis primaevae fundationis fundi Chmielek competen$\mathrm{te}^{\mathrm{a}}$

$1 \mathrm{mo}$

In erectione ecclesiae collegiatae de iure patronatus habentur haec formalia: De iure patronatus praelatos canonicosque ac in omnibus meis haereditariis bonis plebanos ac reliquos sacerdotes praesentandi, cum diutius mecum recogitarem, ne minus digni alias alia de causa praesentarentur ${ }^{62}$, tandem ita mihi visum est penes successores meos ${ }^{63}$ esse debere. Eligendi erunt ad eius-modi sacerdotia ecclesiae ex accademicis docti et boni viri, ad parochialium ${ }^{64}$ etiam vicarii; et ad iudicandum ${ }^{65}$ decanus cum collegio praelatorum et canonicorum adhibendus.

Super quibus verbis reflecti supplicamus. Primo dicit fundator ${ }^{60}:$ De iure patronatus praelatis canonicosque et subiungit ${ }^{c}$ ac in omnibus meis haereditariis bonis pleba$\underline{n o s^{c}}$ etc., ecce omisit vicarios, quos ponere post canonicos debuisset tanquam ad idem corpus ecclesiae cum praelatis et canonicis pertinentes, cur non posuit, ergo signum est, quod illos noluit comprehendi sub iure patronatus ad se suosque successores pertinente.

Nec refert primo, quod scripserit: In omnibus meis bonis plebanos aliosque sacerdotes etc., nam hic per ly: alios sacerdotes non intelliguntur vicarii, quando quidem

"Podstawą wydania jest 10-stronicowy poszyt znajdujący się w Wojewódzkin Archiwum Państwowym w Lublinie, w Zespole Akt Kolegiaty Zamojskiej, nr 64. Tekst rękopisu został przygotowany zgodnie z Instrukcjq wydawniczq dla źródel historycznych od XVI do polowy $X I X$ wieku, red. K. Lepszy, Wrocław 1953. Ponieważ Instrukcja dotyczy przede wszystkim źródeł proweniencji świeckiej wprowadzono do niej pewne modyfikacje. Polegają one na konsekwentnym rozwinięciu skrótów występujących $w$ dokumencie, w tym tytulatury np. venerabilis, reverendus. Bez zmian pozostała jedynie numeracja poszczególnych części rękopisu (tj. $1 \mathrm{mo}, 2 \mathrm{do}$ ) oraz skróty używane w opisach bibliograficzny cytowanych źródeł i opracowań. Ujednoliceniu uległa pisownia dużych i małych liter. Duże litery zastosowano tylko w nazwach miejscowych, określeniach Królestwa Polskiego i Ordynacji Zamojskiej oraz na początku cytatów, o ile było tak w podstawie wydania. W cytatach zamiast cudzysłowu występuja, zgodnie $\mathrm{z}$ podstawą wydania, podkreślenia poprzedzone dwukropkiem. Podkrcślone zostały takżc, zgodnie z treścią rękopisu, opisy bibliograficzne wykorzystywanych źródeł prawnych i traktatów kanonicznych.

${ }^{a} \mathrm{Na}$ ostatniej stronie znajduje się nieco inny tytuł: „Rationes pro iure providendi vicarios ad collegiat[am] Zamoscens[em] canonicos fundi Chmielek concernente".

${ }^{b}$ Numeracja poszczególnych części znajduje się na marginesie rękopisu.

${ }^{62}$ Wydany przez A. Wadowskicgo dokument fundacyjny zawiera w tym micjscu słowo „praesententur”, Wa d o w ski, Wiadomości, s. 84.

${ }^{63}$ Tamżc: "mcos illud".

${ }^{64}$ Tamże: „parochialia”.

"6s Tamże: „diiudicandum”.

${ }^{66}$ Chodzi o Jana Zamoyskiego (1545-1605), I ordynata, hetmana i kanclerza wielkiego koronnego, T. Z i elín s k a, Poczet polskich rodów arystokratycznych, s. 465-467; S. Grzy bow s ki, Jan Zamoyski, Warszawa 1994.

c-c Podkreślenia fragmentu ,ac (...) plebanos" nie ma w rękopisie, ale powinno być, gdyż autor konsekwentnie podkreślał wszystkie zapożyczenia z dokumentów. 
loquitur de sacerdotibus qui per praesentationem ac per consequens per institutionem (quae institutio de iure subsequitur praesentationem) vocantur ad beneficia in bonis Ordinationis, ut patet ex verbis: Aliosque sacerdotes praesentandi, vicarii autem nunquam per viam praesentationis, sed per viam provisionis a canonicis [2] sibi inscribi solite suos vicarios penes collegiatam Zamoscensem obtinebant.

Nec refert secundo, quod fundator scripserit generaliter: in omnibus meis bonis plebanos ac reliquos sacerdotes praesentandi ac per consequens, quod sub vocibus aliosque sacerdotes comprehenderit vicarios ecclesiae collegiatae, quia alias, quod in omnibus quindecem beneficiis intra Ordinationem sitis quorumvis vicariorum praesentationes sibi suisque successoribus reservasset, per consequens, quod domini praepositi, plebani a condita Ordinatione non interruptim provisiones suis vicariis inscribentes ad haec usque tempora, iura Ordinationis impie convellebant hancque convulsionem nullus illustrissimorum ordinatorum nullus ministrorum Ordinationis advertit, quod dicere nefas. Si itaque sub illa generalitate: in omnibus meis bonis aliosque sacerdotes praesentandi dicantur comprehendi vicarii ecclesiae collegiatae, nimium certe probabitur per consequens nihil. Debet ergo illa generalitas intelligi in sensu accomodo conformiter iuri et praxi, nimirum de beneficiis in titulum erectis vel erigendis, qualia sunt praepositurae, plebaniae, ecclesiae hospitalares, ad quae utique de iure acquiritur ius patronatus ex fundatione constructione dotatione, ac per consequens, quae conferuntur praevia praesentatione, ut patet ex voce: Praesentandi, non vero per provisionem officiose inscriptam, qualiter conferebantur ad haec usque tempora vicariatus ecclesiae collegiatae et conferri solent vicariatus in ecclesiis parochialibus.

Tandem cum agitur de promotione vicariorum ad beneficia, meminit eos expresse fundator, ibi: ad parochialium etiam vicarii, ergo etiam ubi agitur de praesentatione meminisset expresse vicarios, ne alias aliorum quam suo potius favori attendisset, quod quia non fecit, signum est quod eos noluerit comprehendi sub suo iure patronatus.

Dein reflecti supplicamus super verbis in erectione positis: eligendi erunt ad eiusmodi sacerdotia collegitae ecclesiae ex accademicis docti et boni viri ad parochialium etiam vicarii, ecce determinavit fundator pientissimus personas eligendas ad sacerdotium ecclesiae collegiatae et ad parochiales, et non determinavit ad vicariatus, manifesto indicio, quod eos a se suisque successoribus eligi noluit, sed a capitulo.

Nec valet dicere vicarios contineri sub voce sacerdotii collegiatae, nam per sacerdotia hic intelligit [3] fundator praelatos et canonicos et non vicarios, quis enim diceret eligendos esse ad vicariatus accademicos, quorum officia accademica sunt incompatibilia cum officiis vicarialibus, et quibus in praemium meritorum in Accademia assignantur praelaturae et canonicatus, non vero vicariatus, alias enim miserum esset praemium accademicorum.

Ad extremum fundator pientissimus praelatos et canonicos iudices subiectorum vocandorum ad beneficia ecclesiae collegiatae et alia parochialia intra Ordinationem constituit, vicariatus tamen eidem iudicio non submisit, ex eo quod gnari subiectorum praelati et canonici ad eosdem vicariatus subiecta vocare et communi iure aliarum collegiatarum in Regno Poloniae (quibus collegiatis et Zamoscensis per summos pontifices et serenissimos reges coequata) providere pro utilitate curae animarum et hori exigentia debeant. Iidem-que vocantes et providentes Deo et iurisdictioni ecclesiasticae de subiectorum, praecipue vices suas obeuntium, respondere teneantur.

2 do

Idem fundator pientissimus fundavit vicarios decanales et canonicales, aeque in bonis immobilibus aeque cum determinatione certae quotae annuae pensionis, nimi- 
rum florenorum septuaginta et tamen vocationem eorum reliquit decano per verba ibi: quos vicarios ipse decanus deliget, praesumendum quod idem esse voluerit cum vicariis canonicalibus, maxime cum non constet de expressa reservatione vicariorum canonicalium et alias non est maior ratio, quare horum vocationem sibi reservasset, potius quam illorum utpote aequaliter (ut dictum est) in fundatione positorum et idem corpus ecclesiae cum aliis constituentium.

3 tio

A condita collegiata per annos 130 semper canonici vicarios vocabant et nec unus quidem actus praesentationis per ipsum saltem fundatorem aut eius immediatum successorem gestus ostendibilis est, ut constat ex decreto visitationis collegiatae per illustrissimum et reverendissimum Turski episcopum Hełmensem ${ }^{67}[s]$ anno praesenti expedite, in quo decreto testatur idem illustrissimus episcopus, utpote requisitus in actis suis episcopalibus et consistorialibus consulto quaesivisse et nullum vestigium provisionis per illustrissimos haeredes, ordinatos, ad vicariatus ecclesiae collegiatae invenisse, sicut tamen inveniuntur praesentationes eorum ad praelaturas, canonicalus ac alia beneficia curata.

4 to

Positive probatur ius vocandi vicarios privative pertinere ad canonicos ex statutis primaevis capitularibus, ibi: Vicarii praebendae Chmielecensis, quando desunt, cura [4] reverendorum dominorum scholastici et canonicorum suffici debebunt. Ecce capitulum onus curandi vicarios canonicis fundi Chmielek imposuit, tanquam illis quorum loco vicarii vices gerunt in choro.

5to

Probatur idem ius ex eo, quando quidem celsissima Catharina Zamoyska ducissa ad Ostrog ${ }^{68}$ illustrissimi olim Thomae Zamoyski Regni cancellarii coniux ${ }^{69}$, in erectione seminarii 12 clericorum anno Domini 1640 die 20 martii facta et manu propria subscripta, diserte testatur in haec verba: Promovendi erunt (id est clerici) ad ordines sacros ad provisionem praecipue capellae Transfigurationis Domini, tum vicariatus ac mansionariatus eiusdem ecclesiae, quas provisiones literas exigente ministeriorum dictae capellae et ecclesiae necessitate ordinandis venerabile capitulum dare debebit. Ecce clarissima mentio provisionis per venerabile capitulum et non per illustrissimos haeredes ordinatos, prout ad haec usque tempora fieri solet. In antiquis autem verba enuntiativa plene probant.

Hic supplicamus reflecti praefata celsissima ab Ostrog Zamoyska ab erecta collegiata post decennium fecit erectionem sui seminarii, in hac obligavit venerabile capitulum, ut illud et non quis alius clericis ordinandis inscriberet provisiones ad vicariatus collegiatae. Ergo ne praefata fundatrix, annis viginti suo illustrissimo marito convivens, ignoravit praxim et consuetudinem respectu providendorum vicariorum, ergo ne ignoravit actus a suo marito gestos, ergo ne filio suo unigenito Joanni post palatino Sandomiriensi ${ }^{70}$ mater dilectissima praeiudicare voluit, res conceptu impossibilis.

${ }^{67}$ Feliks Paweł Turski (1729-1800), biskup chełmski w latach 1765-1771, nastçpnie biskup łucki oraz krakowski, P. N i t c c k i, Biskupi Kościola w Polsce. Slownik biograficzny, Warszawa 1992, s. 212.

${ }^{68}$ Katarzyna Zamoyska, z d. Ostrogska (zm. 1642), wojcwodzianka wołyńska, żona Tomasza Zamoyskiego II ordynata, Z i eli ńs ka, Poczet, s. 467.

69 Tomasz Zamoyski (1594-1638), syn Jana, II ordynat, kanclerz wielki koronny, tamże, s. 467.

${ }^{70}$ Jan Zamoyski (1627-1665), syn Tomasza i Katarzyny, III ordynat, wojewoda sandomierski, tamżc, s. 467-468. 
Accedit, quod illustrissimus Joannes Zamoyski palatinus Sandomiriensis, testamento ultimae voluntatis anno 1665 confecto, cessit de iure patronalus ad omnia beneficia intra Ordinationem sita favore capituli ecclesiae collegiatae Zamoscensis: ażeby konfuzji nie było in conferendis beneficiis ecclesiasticis dominii Zamoscensis, konformujac sie do woli in fundatione Accademiae świętej pamięci jaśnie wielmożnego jegomości pana dziada mego, collationem ich cało i zupełnie oddaje venerabili capitulo ecclesiae collegiatae Zamoscensis, gdyż oni najlepiej wiedza subiecta sposobne w Akademii, klórym te beneficja $z$ fundacji i ze zwyczaju należa. Illustrissimus Martinus Zamoyski thesaurarius Regni ${ }^{71}$, post fata memorati Joannis palatini Sandomiriensis reasumendo dominium [5] Ordinationis Zamoscensis, non attenta praefata cessione reasumpsit simul ius patronatus ad beneficia Ordinationis. Iam si ius providendi vicarios pertinuisset ad illustrissimos Ordinationis haeredes, utique et illud procul dubio reasumpsisset, alias enim quo ad aliqua esset iurium Ordinationis vindex, quo ad aliqua non, quod supponere non licet, quia itaque hoc non fecit, signum est, non ad illustrissimos Ordinationis haeredes, sed ad canonicos praefatum ius vocandi vicarios ex voluntate fundatoris pertinuisse.

6to

Per annos 130 tot intercesserunt visitationes ecclesiae collegiatae, et nullus illustrissimorum episcoporum facit mentionem in decreto suo provisionis ad vicariatus per illustrissimos fundatores factae aut faciendae, imo saltem alicuius requisitionis super hoc ad se delatae.

\section{$7 \mathrm{mo}$}

Est praxis cathedralium et collegiatarum ecclesiarum in Polonia, quod licet canonicatus sint a regibus caeterisque fundatoribus erecti, vicarios tamen aliumque inferiorem clerum providendi relicta est potestas capitulo vel canonicis, ut constat ex praxi vicinae ecclesiae collegiatae Ołycensis, ubi licel canonici cum vicariis a celsissimo Radziwit ${ }^{72}$ in iisdem bonis sint fundati, imo eandem mensam communem inseparabiliter habeant, quisque tamen canonicus primae fundationis de suo sibi providit vicario independenter a celsissimis principalibus Radziwiłow, maxime quia cum vicarius sit vices gerens alterius, scilicet sui principalis, naturae ordo postulat, ut quisque principalis de suo sibi provideat vicario, cum alias pro illo in casu negligentiae respondere teneatur. Praesumendum ergo est, quod et pienissimus fundator Zamoyski hanc praxim aliarum collegiatarum in sua quoque collegiata Zamoscensis sequi voluerit, nec tam onerosam obligationem curandi vicarios idoneos sibi suisque successoribus imponere praetenderit, unde parum honoris et multum oneris.

8 vo

Modi quibus probatur alicui competere ius patronatus a iure canonico recensentur sequentes. Primo. Ex multiplicatis et sine interruptione continuatis praesentationibus per antiquissimum temporis cursum, qui hominum memoriam excedat, ut loquitur Concilium Tridentinum Sess. 25 C. 9 de Reformationibus ${ }^{73}$.

${ }^{71}$ Marcin Zamoyski (ok. 1637-1689), syn Zdzisława Jana i Zofii, IV ordynat (z młodszej linii), podskarbi wielki koronny, tamże, s. 470.

${ }^{72}$ Kościół parafialny w Ołyce został podniesiony do rangi kolegiaty dzięki dotacji Albrychta Stanisława Radziwiłła z 1631 roku. Erekcji dokonał biskup Achacy Grochowski 15 stycznia 1632 roku, L. Kr ól i k, Organizacja diecezji luckiej i brzeskiej od XVI do XVIII wieku, Lublin 1983, s. 213-214.

${ }^{73}$ Zob. Conciliorum Oecumenicorum Decreta, cur. J. Alberigo, Basilcae 1962, s. 765767. 
Secundo. Ex praescriptione quadragenaria cum titulo colorato aut isto deficiente tanti temporis, cuius initii non extet memoria c. episcopus lmo iunct. gloss. v. legitimi de praescript. in 6to. ${ }^{74}$; Gonzal. ad reg. 8va cancell. gloss. 18. n. $57^{75}$; Pal. part. 3tia n. 6to. ${ }^{76}$; Vigesthner de iur. patr. n. $180 .{ }^{77}$

[6] Tertio. Per famam, si cum ea concurrant alia adminicula, praesertim longissima 20 vel plurium annorum possessio, etiam unico actu inducta Gonzal. loc. cit. $\mathrm{n}$. 55 ${ }^{78}$; Pal. n. 6to. etc. ${ }^{79}$; Vigesth. n. $188^{80}$ et fuit resolutum in Aret. Capel. Cap. 6 Dec. 1598 coram Seraphino et aliis 7 test. Gonzal. loc cit. $^{81}$

Qui quidem modi cum manifeste reperiantur in canonicis, ut sine haesitatione constat, indubitatum est penes illos esse ius providendi vicarios collegiatae Zamoscensis.

9no

Accedit decretum illustrissimi Valentini Wężyk episcopi Hełmensis ${ }^{82}[s]$ latum super permutatione modi providendi vicarios Zamoscenses, scilicet provisionis in modum praesentationis et institutionis, Skierbieszoviae die 21 mensis $\left[{ }^{d}\right]$ anno Domini 1765 in haec verba: Iam autem ius patronatus eorundem vicariorum fundi Chmielek penes perillustrem reverendum scholasticum et quatuor canonicis eiusdem fundi uti illis competens ad vicariatus collegiatae Zamoscensis.

Idem testatur novissimum decretum visitationis collegiatae Zamoscensis per illustrissimum episcopum Turski anno praeterito latum et propositum sibi dubium super iure patronatus ad vicariatus collegiatae Zamoscensis resolvit ac penes canonicos esse debere declarat.

${ }^{74}$ Chodzi tutaj o fragment Księgi szóstej (Lib. sextus, lib. 2, tit. 13, c. I), z którego często korzystali kanoniści XVII i XVIII wieku omawiając przedawnienie prawa patronatu, np. P. Pia se cki, Praxis episcopalis, Cracoviae 1627, s. 500, czy L. F e r r a r is, Prompta bibliotheca canonica, irridica, moralis, theologica, nec non ascetica, polemica, rubricistica, historica, t. 4, Parisiis 1861, kol. 1236.

${ }^{75}$ Bez wątpienia chodzi o dzieło: Hieronymus Gonzalez (zm. 1609), Glossema ad regulas VIII cancellariae, Francofurti 1610, kolejne wydanie: Romae 1611.

${ }^{76}$ Katalog ksiazzek biblioteki Akademii Zamojskiej sporządzony w 1800 roku (Cathalogus generalis librorum existentium in Bibliotheca Academiae Zamoscensis die 1 septembris 1800 , Bibliotcka Ordynacji Zamojskich, sygn. 1654, k. 53v) podaje tytuł: P a l e o l i, Codex de iudicis officio. Z pewnością chodzi o dzieło: Michael Angelus Paleoli (ur. ok. 1710), Res iudiciales in quatuor codices distributae, Codex I. De iudicis officio, Romae 1750.

${ }^{77}$ Chodzi tutaj prawdopodobnic o fragment dzieła: Stephan Wies tne r, Institufiones canonicae: sive ius ecclesiasticum, Monachi 1705-1706.

${ }^{78}$ Zob. przyp. 75.

${ }^{79}$ Zob. przyp. 76.

${ }^{80}$ Zob. przyp. 77.

${ }^{81}$ Audytorem sprawy podanej w rękopisie był Scraphinus Olivarius Razzalius, znany także jako Olivier Seraphin (ok. 1533-1609), sędzia od 26 listopada 1565 roku, dzickan Roty od 7 września 1590 do 26 sierpnia 1602 roku (Catalogus RR. PP. Sacrae Rotae Romanae auditorum, w: Sacrae Rotae Romanae decisionum recentiorum, ed. Prosperus Farinaccius, pars 1, Venetiis 1697). Jego orzeczenia zostały wydane w Rzymic w 1613-1614 roku (Aureae decisiones) oraz w Wenecji w 1618 roku (Decisiones aureae).

${ }^{82}$ Walenty Wężyk (1705-1766), biskup chełmski w latach 1753-1765, potem biskup przemyski, N i t e ck i, Biskupi, s. 220.

"W rękopisie pozostawiono wolne miejsce na wpisanie miesiąca, w odpisie $w$ aktach sądowych został wpisany lipiec, AAL. Rep60 A136, s. 15: mensis iulii. 


\section{$10 \mathrm{mo}$}

Adstipulatur his omnibus ultimus status specifice respiciens praefatum ius canonicorum. Nam in praecedenti vocatione fuerunt per eos praesentati reverendi Boguc$\mathrm{ki}^{83}, \mathrm{Piecek}^{84}$, Kisielowski ${ }^{85}$ et Barański ${ }^{86}$. Regulare autem est in beneficialibus, quod pro dignoscenda nalura beneficiorum et qualitate iuris patronatus plurimum attenditur ultimus status ad vulgatum statum in capitulo consultione de iure patronatus, quem late in proposito expendit Rota in Compostelana parochialis 25 iunii 1697 \& illius quippe et 28 iunii 1697 fin. coram R. P. D. Priol, et allibi passim ${ }^{87}$.

\section{$11 \mathrm{mo}$}

His addimus ex abundanti quod dato non concesso praefatum ius patronatus competiisset illustrissimis haeredibus ordinatis, id tamen eis legitime amissum esset per praescriptionem plusquam centenariam, ut recte advertunt Fridericus de Senis con-

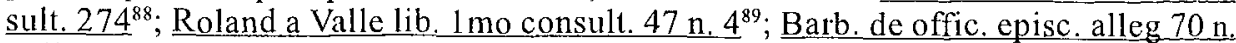
$19^{90}$; Palao. tract. 13 dist. 2 da p. 2 da n. $12^{91}$; Viest. n. $173^{12}$ et communiter omnes canonistae cum talis praescriptio aequivaleat privilegio ut volunt iura.

[7] Nec suffragantur in contrarium literae donationis bonorum Chmielek in actis tribunaliticis Lublinensibus recognitae, in quibus deserte fundator pientissimus reservat sibi ius patronatus ad omnes praelaturas, canonicatus, et vicariatus, in ecclesia collegiata Zamoscensi, nam perpensis praemissis matureque discussis, praeterquam quod praefata donatio sit actus saecularis, dicendum est omnino additionem eiusmodi respectu vicariorum factam esse privata voluntate scriptoris, et praeter imo contra voluntatem pientissimi fundatoris. 'Voluntas quippe interdum ex scientia et patientia induci[tur] 1.1. $\S 11$. ff. ad S. C. Maced. ${ }^{93}$ Inintelligibile enim est, quomodo fundator

${ }^{43}$ Michał Bogucki, zob. przyp. 11. Skądinąd nieznany.

\$4 Antoni Piecek, zob. przyp. 11. Skądinąd nieznany.

rs Andrzej Kisielowski, zob. przyp. 11. Skądinąd nieznany.

${ }^{86}$ Marcin Barański, zob. przyp. 11. Skądinąd nieznany.

${ }^{87}$ Orzecznictwo Roty było czerpanc prawdopodobnie z Sacrae Rotae Romanae decisiones recentiores. Pięć tomów tego wydawnictwa znajdowało się w Bibliotece Akademii Zamojskiej (Cathalogus generalis, k. 53). Chodzi prawdopodobnie o wydanie mediolańskie z lat 17301731. Audytorem sprawy podanej w ręopisie był Aloysius Priolus, sędzia od 10 grudnia 1689 roku (Catalogus RR. PP. Sacrae Rotae Romanae auditorum).

${ }^{88}$ Chodzi tutaj prawdopodobnie o dzieło: Fridericus de Senis (także Federico Petrucci), Consilia et quaestiones, Lugduni 1545, kolejne wydania: Venetiis 1570 (Consilia, sive responsa, quaestiones, et placita), Venctiis 1576 (Consilia, sive navis responsa, quaestiones, et placita)

${ }^{49}$ Chodzi tutaj najprawdopodobniej o dzieło: Rolandus a Valle, Consilia sive responsa, Lugduni 1573, kolejne wydania: Venetiis 1576, Francofurti 1584, Lugduni 1588.

${ }^{90}$ Chodzi tutaj o dzieło: Augustinus Barbosa (1590-1649), Pastoralis solicitudinis sive de officio et potestate episcopi tripartita descriptio, Parisiis 1625 , kolejne wydania: Lugduni 1628 , Lugduni 1641, Lugduni 1656, Lugduni 1665, Lugduni 1666, Lugduni 1679, Lugduni 1698.

${ }^{91}$ Zob. przyp. 76.

${ }^{42}$ Zob. przyp. 77.

${ }^{\mathfrak{c} \cdot c}$ Lekcja niepewna. Fragment ten został dopisany na marginesie pismem mniejszym i przez to niewyraźnym.

${ }^{93}$ Chodzi tutaj o fragment Digestów, jednak dokładna jego lokalizacja jest wątpliwa. Najprawdopodobniej chodzi o: $1.7 \S 11$ D. 14,6, chociaż do treści bardziej pasuje ustęp wcześniejszy: 1.1 \& D, 14,4 (Corpus iuris civilis, vol. I: Digesta, rec. T. Mommsen, Berolini 1895, s. 193). 
pientissimus eiusmodi intentionem et voluntatem suam ad effectum non deduxisset? Quomodo filius eius Thomas vestigia eius secutus non fuisset? Quomodo illustrissima de Ostrog Zamoyska consors illustrissimi Thomae Zamoyski in literis erectionis sui seminarii contrarium fieri iussisset? Quomodo illustrissimus Martinus Zamoyski illud cum iure patronatus ad alia beneficia non reasumpsisset, quomodo tot successores Zamoscii, tot episcopi visitantes errorem hunc, contra voluntatem fundatoris non cognovissent? Ob intercurrentiam ergo tantorum inconvenientium ac caeterorum praemissorum, non ad verba hic, sed ad mentem et intentionem fundatoris attendendum est, cum alias in omni dispositione mens disponentis est velut regina, quae semper attendi

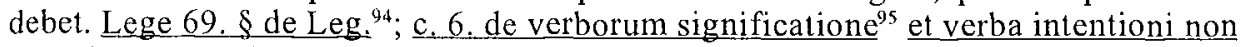
intentioni deservire debet clamat commune axioma iuris.

Nec suffragatur secundo, quod dicitur ab aliquibus praefatum ius patronatus aquisitum esse canonicis mera usurpatione, nam hic ius [8] patronatus sibi competere contendunt personae et communitas ecclesiastica, in his enim praesumptio usurpationis cessat Moedo dec. $340^{96}$; Barbosa de offic. episc. alleg. 62 n. $64^{97}$ et hoc teste Rota in Laudensi iuris patronatus 28 iunii 1630 coram domino Pirogano ${ }^{98}$, ubi fuit resolutum praesumptionem usurpationis non cadere in monasterium aut ecclesiam dominam castri cum sit iusticiae cultrix.

Item cessat praesumptio usurpationis quando beneficiorum collator est aeque ac magis potens, ut iuris patronatus usurpationi suique iuris diminutioni facile possit resistere. Corrad. lib. 4. Prax. benef. c. 4 a n. $40^{99} ;$ Barb. loc. cit. n. $62^{100}$; Palao n. $7^{101}$; Viesthner n. $147^{102}$ et ita resolvit Rota apud Farin. dec. 578. n. $2^{103}$. Quia ratione aequalis potentiae non foret permissurus iuri sibi debito derogari.

Nec suffragatur tertio, quod dicit manifestationem in hac causa nomine illustrissimi Clementis ordinati Zamoyski ${ }^{104}$ coram actis notarii apostolici contra canonicos usurpatores iuris sui esse interpositam. Nam haec manifestatio, praeterquam quod illegitime et sine fundamento facta, nihil operatur, cum sit post bellum consilium, nimirum post praescriptionem plusquam centenariam sufficientissime completam, et alias cum

${ }^{94}$ Chodzi tutaj o fragment Digestów: 1. 69, D. 32 (Corpus iuris civilis, s. 453).

${ }^{95}$ Chodzi tutaj o fragment Dekretałów Grzegorza IX (Gregorius IX, Decretales, V, 40, 6).

${ }^{* 6}$ Chodzi tutaj o dzieło: Ioannes Mohed a u s, Decisiones Rotae Romanae, Romae 1591, kolejne wydania: Marpurgi 1603, Romac 1604.

${ }^{97}$ Zob. przyp. 90.

${ }^{18}$ Zob. przyp. 87. Audytorem sprawy podanej w rękopisie był Philippus Pirovianus, sędzia od 8 lutego 1610 oraz dziekan Roty od 8 stycznia do 10 września 1641 roku (Catalogus RR. PP. Sacrae Rotae Romanae auditorum).

${ }^{99}$ Chodzi tutaj z pewnością o dzieło: Corradus P y r r h u s (1602-1666), Praxis beneficiaria, Venetiis 1671, kolejne wydania: Venetiis 1699 , Venetiis 1735 . Znajdowalo sic ono w zbiorach Akademii Zamojskiej, Cathalogus generalis, k. 65.

${ }^{100}$ Zob. przyp. 90.

101 Zob. przyp. 76.

${ }^{102}$ Zob. przyp. 77.

${ }^{103}$ Chodzi z pewnością o dzieło: Prosper Far in a c i u s (1554-1618), Decisionum Rotae Komanae, Lugduni 1612, kolejne wydania Lugduni 1617, Lugduni 1640 (także tytuł: Sacrae Romanae Rotae decisionum, Venetiis 1618, Venetiis 1622, Aurclianae 1623, Lugduni 1633, Venetiis 1697, Venetiis 1716).

${ }^{104}$ Klemens Zamoyski (1747-1767), syn Tomasza Antoniego i Anieli Teresy, VIIl ordynat, Ziel ińs k a, Poczet, s. 471-472. 
nulla protestatio habeat vim de iure interrumpendi praescriptionem iuxta L. 13 \& pro emptore ${ }^{105}$ multo magis non habebit vim tollendi praescriptionem plusquam legi plenissime completam. Vel si praetenditur eiusmodi manifestatio esse legitima, quare ergo prosecutio causae ad quam praefata regulatur manifestatio, hucusque non subsecuta ut veritas appareat dicimus causam. Quia illustrissimus Clemens ordinatus informatus bene qualitate negotii praesentis scilicet iuris patronatus per illustrissimum dominum Felicem Turski episcopum, in cuius ad dioecesim primo adventu prosecutionem interdixit, super quo testes [9] appellamus ipsum praefatum illustrissimum episcopum et illustrissimas Zamoyskie primam matrem ${ }^{106}$ alteram consortem ${ }^{107}$ praefati olim illustrissimi Clementis ordinati.

Nec suffragatur quarto, quod illustrissimi ordinati iurent super manutentione iurium Ordinationis, nam praefatum ius patronatus, cum probetur competere canonicis vel ad maximum legitime translatum esse in canonicos, amplius non est ius Ordinationis sed ecclesiae, quinimo ex hoc ipso iuramento melius formatur argumentum favore canonicorum. Illustrissimi ordinati, cum iurant super bonis Ordinationis manu tenendis, iurant simul super iuribus manu tenendis ecclesiarum suae Ordinationis, ut patet ex forma iuramenti in Ordinatione praescripta, sed ius patronatus, de quo ad praesens controvertitur, est ius ecclesiae, ut probatum, ergo illustrissimi ordinati iurant super manu tenendo penes ecclesiam praefato iure patronatus.

$\mathrm{Nec}$ suffragatur quinto (quod a quibusdam oppositum est) illustrissimos ordinatos nescivisse de hoc iure, et ideo eo thon usos fuisse, nam hoc dicere est dicere contra prima principia iuris. Praescriptio enim, cum sit introducta, in paenam negligenter et oscitanter iura sua custodientium currit et datur etiam contra ignorantes. Alias quis prudens sciens ius suum ab altero usurpari istud permitteret, nisi forte illud libenter donare vel cedere vellit.

${ }^{105}$ Chodzi tutaj o fragment Digestów: 1. 13 D, 41, 4 (Corpus iuris civilis, s. 663).

${ }^{106}$ Aniela Teresa z Michowskich, $Z$ i e li ńs ka, Poczet, s. 471.

${ }^{107}$ Konstancja Czartoryska z Korca, tamże, s. 472. 


\section{DAS PATRONATSRECHT DER KOLLEGIATSVIKARE IN ZAMOŚĆ IM LICHTE DER REFLEXIONES SUPER IURE PRASENTANDI VON 1770}

\section{Zusammenfassung}

Der Artikel behandelt die Problematik des Konflikts um das Patronatsrecht der Kollegiatsvikare in Zamość, der in der zweiten Hälfte des 18. Jahrhunderts vor dem Gericht des Bischofs von Chełm entbrannte. Im Jahre 1765 entschied der Bischof von Chełm, Walenty Wężyk, über die Umgestaltung von vier Vikarien in Zamoææ ("canonicales"), die bisher nach dem Provisionsprinzip besetzt wurden, in selbständige Pfründen, über die die Domherren von Zamość das Patronatsrecht ausüben sollten. Dies stieß auf den Widerstand der Familie Zamoyski als Hauptstifter sowie der Gönner der Kollegiatskirche in Zamość. Die von den Seiten dieses Rechtsstreits angeführten Argumente bieten eine vorzügliche Gelegenheit zur Analyse der Art und Weise der Berufung der Kollegiatsvikare im neuzeitlichen Polen. Die Begründung des Klägers (d.h. eines Scholastikers und der Domherren von Zamoœæ) unter dem Titel "Reflexiones super iure praesentandi vicarios ad ecclesiam collegiatam Zamoscensem scholastico et caninicis primaevae fundationis fundi Chmielek competente", die in Form eines gesonderten Heftes im Staatlichen Woiwodschaftsarchiv in Lublin aufbewahrt wird, wurde mit einem kritischen Apparat versehen und dem Artikel als Anhang hinzugefügt. 